\title{
Community Forestry in Nepal's Terai Region: Local Resource Dependency and Perception on Institutional Attributes
}

\author{
KC Birendra ${ }^{1}$, Abrar J. Mohammod ${ }^{1} \&$ Makoto Inoue $^{1}$ \\ ${ }^{1}$ The University of Tokyo; Global Forest and Environmental Science, Tokyo, Japan \\ Correspondence: KC Birendra, The University of Tokyo; Global Forest and Environmental Science, Yayoi 1-1-1, \\ Bunkyo-Ku., Tokyo, Japan. Tel: 81-80-4462-1625. E-mail: ecohimalaya@msn.com
}

Received: August 7, 2014 Accepted: August 21, 2014 Online Published: September 22, 2014

doi:10.5539/enrr.v4n4p142 URL: http://dx.doi.org/10.5539/enrr.v4n4p142

\begin{abstract}
Since the 1970s, the implementation of community forestry (CF) programs in Nepal has recognized that local involvement is a prerequisite for sustainably managing forests and fulfilling local resource needs. Although this devolution policy of active local participation has halted and in many cases reversed forest degradation, a comprehensive research on attributes of CF and its impact on local community livelihoods, especially among the rural populations in the low-lying Terai region- is lacking. Hence, using an institutional analysis approach, this research attempts to understand changes in forest management and governance. More specifically, this paper explores major attributes of CF, i.e. the forest, dependency of local people on the forest, institutions that govern local people interaction with the forest and other actors as well as economic and tree cover outcomes. The overall results indicated that most respondents were highly dependent on local forests for economic, ecological and cultural purposes and were collectively involved in creating rules and regulations that defined access to and distribution of CF benefits. The results also indicated that locals' main priorities were to improve their income generation capabilities, whereas CF management primarily emphasized forest protection and local development, as CF-generated funds were used to improve local infrastructure. Hence, the main constraints to CF sustainability were identified to be the CF committee's lack of transparency in fund expenditure and the exclusion of poor and disadvantaged households in the decision-making process. The study concludes that $\mathrm{CF}$ implementation is feasible in the Terai region and that equal decision-making participation is critical toward future CF sustainability.
\end{abstract}

Keywords: community forestry, livelihood, decision making, terai region, Nepal

\section{Introduction}

\subsection{Problem Statement}

The Community forestry (CF) policy in Nepal can be traced back to 1976, when the government formulated the National Forest Plan, which recognized villagers' rights to collectively manage the forest on which their livelihoods depended (Chettri, Larsen, \& Smith-hall, 2012). Furthermore, the Forestry Master Plan of 1989 approved the transfer of tenure rights of all accessible forests in the hills to local control and ownership. A summary of the latest data shows that there are 17,937 community forest user groups (CFUGs), consisting of 2.17 million households and managing 1.6 million ha of forests, a quarter of Nepal's total forestland (DOF, 2011). The survival of the rural Nepalese people is directly linked to forest resources, as many rural Nepalese households are still subsistence users of forest products (Maharjan, Dhakal, Thapa, Schreckenberg, \& Luttrell, 2009). The FAO's 2009 forestry sector outlook study on Nepal comprehensively highlights the importance of community forest products to rural livelihoods (FAO, 2009). In addition, CF has been championed for its positive impact on forest protection and regeneration (Pandit \& Bevilacqua, 2011).

Although CF has been widely devolved in Nepal, only 3\% of the Terai's forest area (totaling 4.5 million ha) has been transferred to local communities (Sapkota \& Odén, 2008). Despite the limited number of CF programs implemented in the Terai region, the $\mathrm{CF}$-managed forests were found to have had better forest coverage than forests under state control (Nagendra, Pareeth, Sharma, Schweik, \& Adhakari, 2008). Nevertheless, research on CF's impact on the Terai population's socioeconomic status is limited (Maharjan et al., 2009). The few available studies about Terai have also been contradictory. Although some researchers credited CF for improving local access to forest resources and fostering local development (Ojha, Persha, \& Chhatre, 2010), others have shown 
pessimism toward the positive role that CF can play in the rural population's socioeconomic viability (Maharjan et al., 2009; Nightingale \& Ojha, 2013; Uprety, Gurung, Bista, Karki, \& Bhandari, 2012).

\subsection{Importance of the Problem}

On the other hand, citing recent scholars' views without considering the positive impact on the environment and local people's livelihoods, the national government has been reluctant in extending the Terai community forestry programs. The government has instead proposed implementing a joint management scheme through which the government controls and defines accessibility and benefit sharing (Banjade, Paudel, Karki, Sunam, \& Paudyal, 2011). However, there is limited research that establishes the Terai CF as an unsuitable policy to manage the Terai forest. For example, the Terai people are highly dependent on the forest for their cooking energy source (fuelwood); nutritional input for livestock, a major source of income generation, is also derived from the forest in the form of fodder, grass and leaf litter. Hence, the dearth of research about CF and its role in the Terai (Maharjan et al., 2009), coupled with a rush to claim CF's implausibility in the region, can have dire consequences for resource governance decentralization and the lives of forest-dependent people (Sunam, Banjade, \& Paudel, 2010). More case studies are needed in the region to obtain a thorough understanding of CF and how it affects local people's livelihoods and local people's role in CF and forest conservation.

Given the limited research on the Terai community forestry programs, this research proposes the following three objectives to fill this knowledge gap. First, we examine CF's institutional set-up by tracking the changes in access rules and authorities since CF's inception. Second, we investigate CF's economic and tree cover contribution. Finally, we assess local people's perceptions and attitudes about CF and community forests. As a means to fill the knowledge gap, the selection of these three objectives is reasonable because they are equivalent to the three $\mathrm{CF}$ attributes discussed below.

\subsection{Theoreitical Framework and Research Design}

Community forestry (CF) is expressed as the "control and management of the forest resources by the rural people who use them for their domestic purposes and as an integral part of subsistence and peasant farming systems (Gilmour \& Fisher, 1991). It has been promoted as a palatable replacement of centralized forest policy to balance conservation and rural development (Ostrom, 1990; Berkes, 1989; Broomley, 1992). Developing nations' shift toward $\mathrm{CF}$ has diverse justifications, including the failure of centralized approaches and pressures from international development agencies (Smoke, 2003; Balooni, Pulhin, \& Inoue, 2008; Pulhin \& Inoue, 2008; Webb $\&$ Shivakoti, 2008). During the centralized regime, inequitable benefit sharing benefited few and marginalized millions, providing another reason to promote decentralized approaches (Pulhin \& Inoue, 2008). Moreover, there is a growing tendency to see people less as a problem and more as a solution with regard to land and natural resource degradation; there is also greater recognition of local populations' important roles in more effectively managing and regulating community forests (Larson \& Soto, 2008).

In Nepal, CF refers to swathes of national forest where tenure rights are given to local communities, called forest user groups (FUGs), for its development, conservation, and management to meet their local needs in a sustainable manner. Based on their own objectives and the condition of the forest, local communities manage the forest by designing and implementing operational plans with support from the Forestry Department (Ojha et al., 2010).

Community forestry is not a monolithic concept. Understanding and analysing CF thus requires investigating each of its attributes. Ostrom (2007) and Basurto \& Ostrom (2008) recently categorized CF attributes as institutions, resource system and units, and CF member attributes. The resource system refers to stock that, under favorable conditions, provides maximum resource units without harming the resource system itself; the resource unit is what a user appropriates from the resource system - e.g., forage, logs, fuelwood and/or non-timber forest products (Ostrom,1990). The important resource system attributes that have been found to have a CF outcome are type, location, productivity and size (Ostrom, 2007). The resource unit's size and its economic value are important attributes that can affect local perceptions and attitudes toward its sustainable management contributions (Ostrom, 1990, Agrawal, \& Lemos, 2007, Basurto \& Ostrom, 2008).

Institutions are rules at work (Ostrom, 1990). They shape one's interactions with others and with resources (Agrawal \& Gibson, 1999). Ostrom (1990) identified three rule levels to analyze the governance process: operational rules, collective-choice rules and constitutional-choice rules (Ostrom, 1990; Ostrom, 2007). Operational rules are rules that affect users' day-to-day decisions about when, where and how to withdraw resource units; who should monitor others' actions and how; what type (positive and negative) of incentives should be employed for different combinations of actions and outcomes. The collective-choice rules are the rules for making operational rules. The constitutional-choice rules are the rules that determine the power structure, the associated powers, and the rules to create, change and revoke the collective-choice rules. 
To comprehend $\mathrm{CF}$ and its outcomes, important $\mathrm{CF}$ member attributes must be considered, such as users' resource dependency (Ostrom, 1990, 1999; Basurto \& Ostrom, 2008). In her principle and design, Ostrom (1990) has underlined the resource's prominence as an important user attribute for providing collective action in commons management. If an individual is highly dependent on a resource, one can assume that he or she places greater value on that resource's long-term sustainability than someone who is not dependent on that resource (Gibson, Mckean, \& Ostrom, 2007). Resource dependency can pertain to economic and/or cultural necessities (Basurto \& Ostrom 2008). Ostrom (2007) also showed that if users do not believe that a resource substantially contributes to their income, they may not be willing to execute collective responsibilities (Ostrom, 2007). As explained by Oakerson (1992), Ostrom (2007) and Basurto \& Ostrom (2008), CF outcomes, which may include improved accessibility, greater resource-generated income, and resource improvements, are the combined results of the aforementioned CF attributes (Oakerson, 1992; Ostrom, 2007; Basurto \& Ostrom, 2008).

\section{Method}

\subsection{Study Site Description}

This research investigates the Gramin Sudhar (GS) CF in the Bayarban Village Development Committee (VDC), Morang district of the eastern Terai region (Figure 1). This is the preferred study region to evaluate livelihood outcomes because it has adequately matured in community forestry program implementation. The community forestry program has been practiced in the region for more than 15 years. Due to the presence of forests with high economic value, the Terai area has been strategically identified as the region with the highest economic potential (Nightingale \& Ojha, 2013), (Ojha, 2008) and is also considered the breadbasket of Nepal (Bista et al., 2013). While it covers only $17 \%$ of Nepal's total land area, the Terai currently accommodates nearly half of the total population (CBS, 2011). With a total population of 843,220 , the district's average literacy rate is $64 \%$ (CBS, 2011). The district is one of the most productive areas in terms of agriculture and livestock and is thus directly linked to the forest. According to the District Forest Office (DFO), the district has 107 registered community forest user groups that manage 7,140 ha of community forest (DFO Office Morang, 2013).

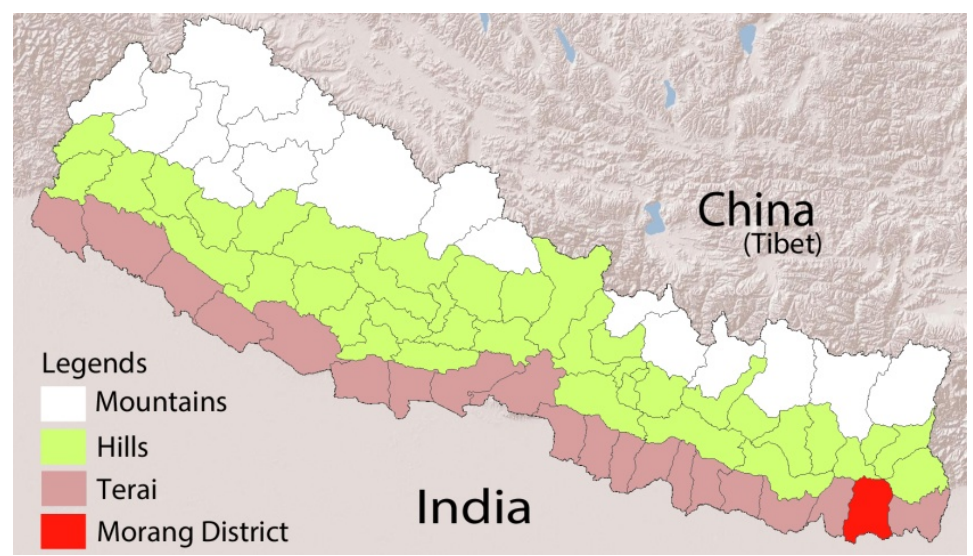

Figure 1. Geographic map of Nepal and Morang district location

Bayarban VDC has 2,729 members in a village with a total population of 13,638. It is located $2 \mathrm{~km}$ from the East-West highway and $35 \mathrm{~km}$ from the district capital of Biratnagar. The village has a heterogeneous ethnic composition, mainly composed of Chettri, Brahmin, Kirat, Newar, and Dhimal communities. A mixed farming system is the main source of livelihood, and farmers primarily farm rice, followed by maize and wheat. Potatoes, mustard and other seasonal vegetables serve as both subsistence and cash crops. Animal husbandry is an integral component of the livelihood system; cattle and buffalo are raised for milk, while pigs, goats and chicken are bred for meat.

\subsection{Data Collection Method}

This study's empirical data were derived from document reviews and structured and semi-structured questionnaire interviews. A total of 281 households (HHs) were randomly selected from the Gramin Sudhar (GS) CF in Bayarban VDC. Document review and a semi-structured interview were utilized to collect data on the CF institution and current forest conditions. To investigate local people's general dependency (i.e., economic, ecological and/or cultural as well as detailed economic dependency), a semi-structured questionnaire was used. 
For example, the respondents were asked to list the type of resources extracted from the community forest and list the different ecological functions provided. A structured questionnaire was used to collect data on the accessibility of forest resources, socioeconomic information (e.g., age, education, land holdings, ethnicity), and the prevailing community attitude about the community forest's function.

Because the survey attempted to gather data about villagers' recollections of past forest activities and their reliance on the forest for their livelihoods, cross-checking and group consensus were necessary to validate the data. Hence, in addition to the survey, group application of the HH questionnaire was employed with at least 5 or more household present at a single sitting. This allowed on-the-spot data triangulation of the information and increased data reliability. As recommended by the FAO (Davis, 1990), PRA tools were utilized to elicit information about forest resource use, livestock holdings and tree plantations on private farmland. Descriptive statistics (e.g., averages, percentages) are used to analyse the quantitative data.

\section{Results}

\subsection{Sampled HHs Characteristics}

The sampled respondents included 197 men (70\%) and 84 women (30\%) (Table 1). The respondent age variation was as follows: $51(18 \%)$ respondents from $18-29$ years of age, $87(30 \%)$ from 30-40, 79 (28\%) from 40-60 and $64(22 \%)$ above 60 . Approximately $18 \%$ of respondents were illiterate, while $82 \%$ had acquired some level of education. This level was higher than the district's literacy rate, which stands at $64 \%$. The study village's comparatively high education level shows potential for greater livelihood improvement through skills training and capacity building. The community's ethnic composition is a heterogeneous mix, with most respondents falling within the Brahimin/Chettri category (33.80\%), followed by Kirats (25.62\%). The Dalits and Indigenous, who are classified as a disadvantaged group, comprised $25.26 \%$. The respondents' ethnicities reflected the community forest user group's ethnic composition, according to the record books (Table 1).

Table 1. Socioeconomic characteristics of sampled households $(\mathrm{n}=281)$

\begin{tabular}{|c|c|c|}
\hline Characteristics & \multicolumn{2}{|c|}{ Respondents } \\
\hline Gender & & \\
\hline Male & 197 & 70 \\
\hline Female & 84 & 30 \\
\hline \multicolumn{3}{|l|}{ Age Structure } \\
\hline$<29$ Years & 51 & 18 \\
\hline 29-40 Years & 87 & 31 \\
\hline $40-60$ Years & 79 & 28 \\
\hline$>60$ Years & 64 & 23 \\
\hline \multicolumn{3}{|l|}{ Literacy Level (school years) } \\
\hline Illiterate $(0$ years $)$ & 50 & 18 \\
\hline Elementary School (1-5 Years) & 100 & 36 \\
\hline High School (6-9 Years) & 93 & 33 \\
\hline Post-secondary (> 10 Years) & 39 & 14 \\
\hline \multicolumn{3}{|l|}{ Land Holdings } \\
\hline Landless & 11 & 4 \\
\hline$<10$ Katta & 162 & 58 \\
\hline$>10$ Katta & 108 & 38 \\
\hline Average land Holding Size (ha) & 0.51 & \\
\hline \multicolumn{3}{|c|}{ Ethnic Composition } \\
\hline Brahmin/Chettri & 95 & 33.80 \\
\hline Kirat & 72 & 25.62 \\
\hline Indigenous & 30 & 10.67 \\
\hline Dalit & 41 & 14.59 \\
\hline Others & 43 & 15.30 \\
\hline
\end{tabular}

Katta $=0.0338$ Hectares. 


\subsection{The Forest and its Resources}

The forest managed by the sampled CF covers an area of 839.22 ha. It is composed of natural forests and plantations. The natural forest is a dense Sal forest with dominant species of Shorea robusta (sal) and mixed species, such as Adina cordifolia, Anthocephalus chinensis (kadam), Ormosia glauca (Bot dhayreo), Acacia catechu (Khayer), ashjare, datrungo, maina kath, pitahri, tatari, and khirra. The plantation forests, primarily located at the forest's edges, include plantations of Dalbergia sisso (sissoo), Eucalyptus globulus (eucalyptus) and Tectona grandis (teak).

The forest serves as a habitat for different types of wild animal and birds, which potentially attract tourists and provide bush meats. Among the commonly present wildlife are monkeys, wolves, wildcats, wild boar, deer, and bears. In addition, the forest area includes a wetland, which serves as habitat for endangered and threatened species and some rare birds. The forest also provides diverse types of medicinal plants, such as Terminalia chebula (harro), Terminalia bellirica (barro), Urtica dioica (sisnu), and Rauvolfia serpentina.

The forest also provides seasonal collections of wild edibles that constitute a major part of the Teraian diet. Among the respondent-cited edibles are Gleichenia dicarpa (niguro), whose shoots are collected during the latter part of the rainy season (July and August) and are very commonly cooked as curry. Other seasonal vegetable species include Diplazium esculentum (koche sag), Ophioglossum petiolatum (jibre sag), mushroom species, Bauhinia variegata (koiralo) and Dioscorea bulbifera (tarul).

\subsection{Local People's Forest Dependency}

An overwhelming majority of the respondents (93\%) have mentioned the forest's environmental benefits as vital to them (Table 2). The following environmental benefits of the forest were cited: water and clean air sources, wild animal refuges and soil erosion prevention. The respondents also stressed that the forest is vital in maintaining farmland fertility through sediment deposition during the rainy season. This response implies that villagers were highly informed about the forest's ecological functions and were willing to participate in protection activities.

Table 2. FUG dependency on the forest $(\mathrm{n}=281)$

\begin{tabular}{lc}
\hline Dependency type & Respondent's percentage \\
\hline Ecological & 93 \\
Cultural & 90 \\
Economic & 97 \\
\hline
\end{tabular}

The community forest also plays an important role in village culture and traditions. During the study, the forest was used as a cremation ground and for other religious festivities. No matter the cluster location, most respondents $(90 \%)$ agreed that the forest was significant for cultural and religious purposes. This finding also indicates that the respondents were aware of the forest's cultural importance.

The highest percentage of dependency, however, fell into the economic category (Table 3), which was mentioned by $97 \%$ of the interviewees. The main community forest products - fuelwood, fodder grass, wild edibles and grazing land-were found to be vital economic dependencies. Fuelwood was the major energy source that villagers used to cook food and prepare livestock feed. All respondents affirmed their dependency on the forest for fuelwood, which is utilized for subsistence and income generation. Fodder and grass were mentioned as vital resources by $98 \%$ of the respondents. Fodder and grass were collected from the forest to feed the livestock, and leaf litter served as bedding materials in the animal stalls and is composted and used as fertilizer during crop and vegetable cultivation. Timber, which $54 \%$ of the respondents mentioned as an important resource, is used to construct houses, make repairs and produce agricultural tools, such as spades, ploughs and levelers.

Ninety-six percent of respondents mentioned edible forest shoots of Dryopteris cochleata (niguro), Diplazium esculentum (koche sag), Ophioglossum petiolatum (jibre sag), mushroom species, Bauhinia variegata (koiralo) and Dioscorea bulbifera (tarul) as an important part of their diets. Eighty-six percent of respondents also mentioned that their livestock previously grazed in the forest before the CF. 
Table 3. Economic dependency on the forest $(n=281)$

\begin{tabular}{lc}
\hline Forest function & Respondent's percentage \\
\hline Fuelwood & 100 \\
Fodder/leaf & 98 \\
Wild edibles & 96 \\
Grazing field & 86 \\
Timber & 54 \\
\hline
\end{tabular}

\subsection{CF Institutional Set-up and Governing Rules}

The village CF was initiated in 1999 and finally approved by the District Forest Department in 2004. Initially, villagers were sceptical about the group's formation, as they feared they would have minimal roles in making operational rules, especially with respect to forest accessibility. Consequently, they were anxious about the potential negative consequences that the $\mathrm{CF}$ could have on their livelihood. However, the Federation of Community Forestry in Nepal (FECOFON) and the DFO, in collaboration with influential and informed villagers, organised awareness campaigns to inform villagers about the objectives and benefits of CF creation.

The core principle for the community-administered forest is based on collective management planning. After the CF's formation, the community was allowed to create its own constitutional- and collective-choice rules that determine operational rules. The constitution and operational plan (OP) provide the guiding principles for the CF's institutional procedures. After discussions with community members, the CFUG prepares the constitutional rule, which stipulates the CF's governance structure accordance with the Forest Act of 1993 guidelines.

The constitution is a set of rules defining management of conflicts with outsiders and/or group members; it also describes benefits, sharing and sanction provisions for rule breakers. The constitution is responsible for the institutional arrangement of the executive committee and the general assembly. Accordingly, by convening the general assembly, the user group selects the executive committee, a 15-person panel, to oversee the CF's daily activities and implement the OP. The executive committee selection is based on the consensus of all community members, as the CF constitution gives members the power to select or replace executive committee members. Hence, the forest user group's principal power lies within the general assembly.

The CF also prepares the OP with technical assistance from district forest officials. The OP is also based on members' consensus, as it is prepared during the general assembly through which all users can debate, raise issues and offer opinions. The OP addresses issues such as management goals, forest boundary demarcation and methods to implement $\mathrm{CF}$ objectives by engaging in particular activities, including harvesting, protection, regeneration and income generation programs. The CF operational plan is prepared for a 5-year period. Through general assembly consensus, the members devolve executive power to the executive committee, which can be withdrawn if members are dissatisfied with their performance or misuse of power.

The CF has created 35 sub-group clusters called "tole" for the allocation of human resources to monitor and carry out management activities. Each tole has an average of $65 \mathrm{HHs}$ that are then assigned certain days to patrol and conduct other management activities, such as tree-planting. A major element of the management plan is the establishment of different forest zone blocks, which are separated according to the degradation level and the ensuing plantation activities in the most degraded areas. The different blocks are prescribed different management schemes according to the OP's description of the block's ecology. Each day, a tole HH contributes a group member who enters the forest to complete the task assigned to him or her. This management plan has allowed the forest to increase its biomass.

\subsection{CF Outcomes}

\subsubsection{Change in Forest Resource Availability and Collection Times}

This study also analysed the community forestry's impact on HH perceptions of forest product availability and collection times. In terms of availability changes for timber, fuelwood, and fodder, respondents were asked the following: (a) whether the product was easily available year round (AV); they had seasonal difficulty primarily during the monsoon season (SD); or (c) the product was very difficult to obtain year round (VD). The respondents were also asked how much time they spent collecting products. The results are presented in Table 4. 
Table 4. Post- $\mathrm{CF}$ changes in forest resource availability $(\mathrm{n}=281)$ (respondent frequency and percentage in parentheses)

\begin{tabular}{lllllc}
\hline Period & Forest resource & AV & SD & VD & Average Collection Time (hrs) \\
\hline \multirow{2}{*}{ Pre-CF } & Timber & $44(16 \%)$ & $158(56 \%)$ & $79(28 \%)$ & (not allowed) \\
& Fuelwood & $79(56 \%)$ & $167(59 \%)$ & $35(12 \%)$ & 3.5 \\
& Fodder & $61(22 \%)$ & $141(50 \%)$ & $79(28 \%)$ & 4 \\
\multirow{3}{*}{ Post-CF } & Timber & $175(62 \%)$ & $71(25 \%)$ & $35(12 \%)$ & Sold in Community Forest \\
& Fuelwood & $202(72 \%)$ & $26(9 \%)$ & $53(22 \%)$ & 1.5 \\
& Fodder & $193(69 \%)$ & $53(22 \%)$ & $35(12 \%)$ & 1.5 \\
\hline
\end{tabular}

Majority of the households (59\%) had difficulty collecting fuelwood during the rainy season. After the establishment of the community forest, this seasonal difficulty dropped to only $9 \%$ of HHs. Year-round fuelwood availability has improved for most households, climbing from $28 \%$ before $\mathrm{CF}$ to $72 \%$ after $\mathrm{CF}$ (Table 4 ). HHs that generated income by selling fuelwood were not allowed to continue the practice in community-managed forests. However, these same HHs also accredited the community forest for employing them as manual labourers to harvest and transport timber.

The availability of fodder also improved, as $193 \mathrm{HHs}$ could collect it from the community forest year round (CF). In addition to the open grazing restriction, the increase in fodder availability can primarily be attributed to the community forest's involvement in planting hybrid grass species in all degraded forest areas. This study's findings are in line with previously reported by Pandit and Bevilacqua (Pandit \& Bevilacqua, 2011). As user groups are engaged in protection, reforestation and planting activities, more forest products, including fodder, are available for community forest members to collect. The findings also demonstrate a notable reduction in forest product collection times. Before the creation of the community forest, users had to spend an average of 3.5 hours collecting fodder and 4 hours collecting fuelwood. The collection time was reduced by $50 \%$ and $56 \%$, respectively, as $\mathrm{HHs}$ only spent 1.5 hours for both activities after the CF's creation (Table 4).

The CF's creation has also allowed the user group to commercialize timber and other NTFPs to generate income, which is then spent for forest management and community development activities. Timber is harvested by collecting fallen trees and chopping up dead or old ones. The collected timber is distributed on a needs basis at a subsidized member price. Any group member requiring timber for consumptive needs, such as building a new house or repairs, applies through an application process. The surplus timber that remains after needs-based community distribution is auctioned to the highest bidder. Publishing the date and place of the auction in a national newspaper, the community advertises the bidding process to the interested sawmills and middlemen. The generated income is then spent on different CF activities as defined in the operation plan. Sometimes, the timber is used to build communal infrastructure, such as schools, temples or small bridges. For example, data gathered from the CF record books indicate that timber was used to build 18 bridges by 2013, and 500 cubic feet of timber was donated to local schools for repairs.

\subsubsection{Changes in Landscape Tree Cover Through PrivateTtree Planting}

The survey also found changes in the number of trees planted on private land, which constitutes agricultural fields (khet) and Bari (Note 1). Fodder- and timber-producing tree species are mostly planted around the field's edges, while fruit trees, such as mangos and lychee, are preferred in the bari. Since the CF's introduction, the number of trees planted by individual HHs on private land has increased from an average of 13 to 30 trees. The CF had established nurseries to provide free saplings to users interested in planting trees on their private land. User tree-planting sessions were conducted under the supervision and technical guidance of one of the local forest office experts. As reported by Dhakal (2009), private tree plantations are an increasing trend in the Terai region. In our case study, this trend can be attributed to the population's increasing awareness of timber's commercial value and the readily available tree saplings from the CF nurseries. This practice of private tree planting is encouraging, as farmers can produce their own fuelwood and fodder and, hence, reduce pressure on the CF. This finding agrees with $89 \%$ of respondents who supported the community forests' creation as the best way to protect forests.

\subsubsection{Overall User Groups' Perceptions of the CF}

From the state to community level, the devolution of resource management responsibilities and associated institutional changes in forest access and management influenced the perception of forest resource sustainability in 
local communities. The respondents were very satisfied with the GS Community Forest's protection of the forest, as $77 \%$ of them approved its performance. The GS Community Forest's income contribution was also appreciated by $71.52 \%$ of the respondents (Table 5). As they perceived that the CF had increased benefits and were able to observe tangible positive impacts for themselves, community members developed positive attitudes toward the management process. Such appreciation of benefits and the positive livelihood impact is an encouraging trend for resource base sustainability.

Conversely, $53.38 \%$, of which $82 \%$ are women, were dissatisfied with the decision-making process. This dissatisfaction may be explained by the low level of participation, particularly among women and disadvantaged groups, in the community forest's decision-making process. Similarly, the 38\% disapproval for GS Community Forest's community development work and the 44\% dissatisfaction with IGA loans provided by the GS Community Forest can be explained by the Community Forest Fund's dis-appropriation for activities contrary to community members' diverse expectations (Table 5). For instance, it has been argued that creation of public infrastructure (e.g., schools and roads) rarely benefits poor and disadvantaged groups. For example, according to Pokharel (2008), poor Nepalese households may not view school buildings as beneficial, as they cannot afford to send their children to school. In our case study, we found similar attitudes, as respondents disagreed with timber donations to build chairs and desks for the local school. However, respondent disagreed with the donation because they believed that the government—not the CF—-should be responsible for maintaining public schools; moreover, the CF could increase its revenue by selling the donated timber. The respondents believed that the generated income could then be invested in income-generating activities for community forest members, such as large-scale poultry farming.

Moreover, respondents were less satisfied with the community forest's transparency and decisions about financial expenditures, as executive committee members and more knowledgeable members are more likely to obtain loans than members of poor and disadvantaged groups. For example, the decision to buy a tractor with GS Community Forest funds was seen as contentious, as most members had small land holdings where tractor ploughing was impracticable. Additionally, members complained that expenditure accountability for tractor maintenance was not forthcoming and vague in nature. Therefore, some of the CF's adopted fiscal policies are found to be ambiguous and sometimes not accountable, which can restrain forest sustainability and detrimentally impact users' livelihoods.

Table 5. Local people's satisfaction with different outcome parameters after CF implementation ( $\mathrm{n}=281)$ (frequency and percentage in parentheses)

\begin{tabular}{llll}
\hline Outcome parameter & \multicolumn{3}{c}{ Level of satisfaction } \\
\cline { 2 - 4 } & Very satisfied & Somewhat Satisfied & Not Satisfied \\
\hline CF's protection of the forest & $215(77 \%)$ & $39(11 \%)$ & $27(10 \%)$ \\
CF's income contribution & $67(24 \%)$ & $134(48 \%)$ & $80(28 \%)$ \\
CF's community development activity & $46(16 \%)$ & $128(46 \%)$ & $107(38 \%)$ \\
CF's capacity-building initiatives & $49(17 \%)$ & $127(45 \%)$ & $105(37 \%)$ \\
CF's decision-making process & $34(12 \%)$ & $63(22 \%)$ & $150(53 \%)$ \\
CF-implemented IGA & $25(9 \%)$ & $132(47 \%)$ & $124(44 \%)$ \\
\hline
\end{tabular}

\section{Discussion}

Community forest policy entails a paradigm shift from centralized, top-down management to more inclusive and participatory forest management. Consequently, the paradigm shift is accompanied by a change in the institution that governs how the forest is managed and utilized (Mohammed, 2014). As witnessed in this study, local people were given more space to devise their own constitution and collective-choice rules that were the basis for the operational rules that shaped farmers' day-to-day activities. Although the CF constitution needs to be in accordance with Forest Act guidelines, these guidelines are flexible, as the user group can incorporate local traditions and practices (Ojha et al, 2010). Community forestry is also about members' collective contributions for sustainable forest management. This willingness to implement the rules is influenced by various factors, including the forests' potential to provide local people with goods and services (Ostrom, 2007) and the critical dependency on forest resources (Ostrom, 1990, 1999; Basurto \& Ostrom, 2008). 
Unlike when the government only allows CF in degraded forest areas with minimum potential to incentivize local forest management, the forest in this study was found to have high potential. This forest has trees that provide timber and non-timber products. The presence of diverse forest wildlife also allows income generation from tourism and provides local people with a bush meat source. Despite its potential, if local people have no interest in the forest, they may not contribute to its sustainability. Therefore, dependency is an important CF member attribute that shapes their motivation to contribute for collective forest management and conservation (Birendra \& Nagata, S. 2006; Ostrom, 2007;). Depending on other meditating factors, the type of dependency also differs from place to place. For example, the CF members in this study were highly dependent on the forest for economic income because of the relatively smaller land holding size $(0.53 \mathrm{ha})$ compared to the national average (0.96 ha) (CBS, 2007). As smaller farm size decreases total product amounts, HHs' dependence on forest products for income generation increases. According to various studies (Byron \& Arnold, 1999; Uprety, Boon, Poudel, Shrestha, Rajbhandary, Ahenkan, \& Tiwari, 2010; FAO, 1997), rural populations that are landless or with smaller land holdings tend to depend more on forest resources than HHs with higher land ownership. This finding also agrees with Karky, Vaidya, Karki, \& Tulachan, (2013), who find that HHs near protected forest areas were more willing to participate in protection activities when they perceive positive contributions to their livelihoods. Hence, immediate livelihood benefits to rural HHs serve as key incentives for effective community forest management (Ojha et al., 2010)

The CF creates such incentives by improving access to these salient goods on which local people depend. For example, in this study and the Niraula et al. (2013) study of community forestry programs in the Dholakha district of Nepal, the community's fuelwood availability after CF implementation increased. However, unlike their claim that the $\mathrm{CF}$ resulted in a more efficient community fuelwood distribution, our case study found that more households had year-round difficulty in collecting firewood. Unfortunately, respondents who were affected by year-round difficulties were those who also derived some of their household income by selling fuelwood. The CF's negative impact on those subsistence- and income-dependent fuelwood collectors is also supported by other studies, such as Mohammed and Inoue (2012a; 2012b) and McDougall, Jiggins, Pandit, Rana, and Leeuwis (2013). This study's CF, nonetheless, made an attempt to minimize the transaction cost impact on the poor by providing preferential treatment to them in employment opportunities.

Such "pro-poor" CF activities are vital in creating incentive for poor villagers; employment opportunities for nursery technicians, forest guards, and wage laborers are increasingly prioritized for poorer community members (McDougall et al., 2013, Bhattarai, 2009). In addition to the incentivizing power of improving resource supply, feelings of ownership also act as incentives to contribute to forest management and conservation. Through the formation of the GS CFUG, community members have become "confident resource managers and are moving into planning wider community development" (Brown, Malla, Schreckenberg, \& Springate-Baginski, 2002). This shift might explain why a large proportion of respondents were satisfied with forest protections, despite the low-income incentive the CF created. Community members' dependency on the forest for cultural and environmental purposes, which was also mentioned by a large portion of CF members, might also explain this satisfaction.

In addition to the forest's income constriction, the CF's decision-making process seemed to have failed the most marginal sect of society, i.e., women. Despite their large share of contributions for forest-related activities (T. D. Allendorf, \& K. Allendorf., 2012), they are largely underrepresented in the executive committee, which is the primary decision-making body in the community forestry (Gupta, Bhattarai, \& Sah, 2011, Pandit \& Bevilacqua, 2011). On the other hand, this disadvantaged group's inability to voice their concerns during meetings can be attributed to its low literacy levels and prevailing traditional customs (Lund et al., 2013). Hence, as this case study has shown, one of the main constrains to effective CF management is passive participation (note 2) in the decision-making process (Sunam et al., 2013). Passive participation can result from a lack of awareness about issues discussed in meetings, which results in fewer opinions expressed (Lewark et al., 2011). These findings concur with those of Blaike et al. (2007), who argued that the bureaucratic structures and cultures within which CFs operate are impediments to successful CF programs. As it has discretionary power in how the CF's finances are handled, the executive committee is not held accountable to general members to devolve information about the exact nature of expenditures.

\section{Conclusion and Policy Implications}

This study explored and explained CF in the Terai region and its outcomes by investigating the resource system and unit, institutions and CF attributes. The study found that the forest given to local people through the CF seemed to have good potential for providing both timber and non-timber products. The creation of the CF has institutionalized the management of the forest where the constitutional, collective and operational rules that dictate 
CF members' interaction with the forest were found to have been created by CF members themselves, mostly through consensus. The institutional set up has allowed the local population to collectively engage in the monitoring, managing, and improving the forest condition as well as sharing the benefit derived from the improved forest condition. The $\mathrm{CF}$ has also encouraged the members to plant more trees in the degraded areas of the forest as well as around their private land, resulting in improved quality and quantity of tree cover in the area.

According to local people, this CF system's outcomes were found to be good in terms of forest protection. However, the income generation and decision-making process were found to be unsatisfactory. The user groups, especially the poor, have high expectations for the $\mathrm{CF}$ to contribute more income-generating activities, which have yet to be fully realized. Hence, one of the CFUG's main challenges will be how to address divergent user group interests. One possible solution would be for the CF to devise plans to adopt poverty alleviation as an explicit goal and invest more money according to its members' aspirations (Pokharel, 2009). Another challenge will be to ensure that all members, especially women and the poor, have equal roles in decision-making processes. Training programs on good governance and literacy classes targeting women and disadvantaged groups could enable them to be assertive and voice their opinions during the CF's decision-making processes. Finally, although this study coveres important issues, i.e.,the institutional setup, forest and livelihood outcome as well as local people perception of CF in the study village, more case studies are needed on these and other diverse attribute of CF and its outcome to protrude the overall picture of CF in the whole Terai region.

\section{References}

Agarwal, B. (2010). Does women's proportional strength affect their participation? Governing local forests in South Asia. World development, 38(1), 98-112. http://dx.doi.org/10.1016/j.worlddev.2009.04.001

Agrawal, A., \& Gibson, C. (1999), Enchantment and disenchantment: The role of community in natural resource conservation. World Development, 27(4), 629-649. http://dx.doi.org/10.1016/s0305-750x(98)00161-2

Agrawal, A., \& Lemos, M. C. (2007). A Greener Revolution in the Making?: Environmental Governance in the $21 \mathrm{st}$ Century. Environment. Science and Policy for Sustainable Development, 49(5), 36-45. http://dx.doi.org/10.3200/envt.49.5.36-45

Agrawal, A., Nepstad, D., \& Chhatre, A. (2011). Reducing emissions from deforestation and forest degradation. Annual Review of Environment and Resources, 36, 373-396. http://dx.doi.org/10.1146/annurev-environ-042 009-094508

Allendorf, T. D., \& Allendorf, K. (2012). The Role of Gender in Park-People Relationships in Nepal. Human Ecology, 1-8. http://dx.doi.org/10.1007/s10745-012-9510-7

Arun, D. (2009). Tree growth performance in private plantations in Nepal's central Terai region. Tropical Forest Update 18/ 3. ITTO, Japan.

Balooni, K., Pulhin, J. M., \& Inoue, M. (2008). The effectiveness of decentralisation reforms in the Philippines's forestry sector. Geoforum, 39(6), 2122-2131. http://dx.doi.org/10.1016/j.geoforum.2008.07.003.

Banjade, M. R., Paudel, N. S., Karki, R., Sunam, R., \& Paudyal, B. R. (2011). Putting Timber in the Hot Seat: Discourse, policy and contestations over timber in Nepal. Discussion Paper Series, 11(2). ForestAction, Kathmandu, Nepal.

Banjade, M. R., Paudel, N. S., Karki, R., Sunam, R., \& Paudyal, B. R. (2011). Putting Timber in the Hot Seat: Discourse, Policy and Contestations over Timber in Nepal. Discussion Paper Series 11:2. Forest Action, Kathmandu, Nepal

Berkes, F. (1989). Common property resources: ecology and community-based sustainable development. Belhaven Press, London.

Bhandari, M., Köfer, J., \& Schobesberger, H. (2011). Livestock production system-challenges in maintaining health and hygiene in rural Nepal: Animal hygiene and sustainable livestock production. Proceedings of the XVth International Congress of the International Society for Animal Hygiene, Vienna, Austria, 3-7 July 2011, Volume 3. (pp. 1407-1414). Tribune EU.

Bhattarai, R. C. (2012). Economic impact of community forestry in Nepal: A case of mid-hill districts of Nepal. Economic Journal of Development Issues, 13, 75-96.

Bhattarai, S. (2009). Towards pro-poor institutions: Exclusive rights to the poor groups in community forest management. Discussion paper. Forest Action Nepal and Livelihoods and Forestry Program, Kathmandu, Nepal. 
Birendra, K. C., \& Nagata, S. (2006). Refugee impact on collective management of forest resources: a case study of Bhutanese refugees in Nepal's Eastern Terai region. Journal of Forest Research, 11(5), 305-311. http://dx.doi.org/10.1007/s10310-006-0231-x

Bista, D. R., Amgain, L. P., \& Shrestha, S. (2013). Food security scenario, challenges, and agronomic research directions of Nepal. Agronomy Journal of Nepal, 3, 42-52. http://dx.doi.org/10.3126/ajn.v3i0.8985

Blaikie, P., \& Springate-Baginski, O. (Eds.) (2007). Participation or democratic decentralization: strategic issues in local forest management. Forest, People and Power. The Political Ecology of Reform in South Asia. Earthscan Publications, 366-385.

Bromley, D. W. (Eds.). (2002), Making The Commons Work: Theory and Practice. California: ICSG press.

Brown, David., Malla, Y., Schreckenberg, K., \& Springate-Baginski, O. (2002). From supervising" subjects" to supporting" citizens": recent developments in community forestry in Asia and Africa. Overseas Development Institute. Retrived from: http://dlc.dlib.indiana.edu/dlc/bitstream/handle/10535/3793/75-community -forestry-asia-and-africa.pdf? sequence $=1$

Byron, N., \& Arnold, M. (1999); What futures for the people of the tropical forests?. World Development, 27(5), 789-805. http://dx.doi.org/10.1016/s0305-750x(99)00025-x

CBS (2011). Nepal Population Census, Kathmandu: Central Bureau of Statistics.

CBS, (2007). Nepal Agriculture Monograph, Kathmandu: Central Bureau of Statistics

Chhatre, A., \& Agrawal, A. (2009). Trade-offs and synergies between carbon storage and livelihood benefits from forest commons. Proceedings of the National Academy of Sciences, 106(42), 17667-17670. http://dx.doi.org/10.1073/pnas.0905308106

Chhetri, B. B. K., Larsen, H. O., \& Smith-Hall, C. (2012). Law enforcement in Community Forestry: consequences for the poor. Small-Scale Forestry, 11(4), 435-452. http://dx.doi.org/10.1007/s11842-011 $-9194-7$

Davis Case, D. (1990). The community's toolbox: the idea, methods and tools for participatory assessment, monitoring and evaluation in community forestry. FAO Community Forestry Field Manual, (2).

Department of Forest. (2011). Status of Community Forestry. Kathmandu, Nepal. DoF. Retrived October 08, 2013, from http://dof.gov.np/division/community-forest-division/community-forestry

DFO (2013). Morang Community Forestry Database; Biratnagar, Nepal.

FAO. (1997). Considering nutrition in National Forestry Programmes. Formulation, implementation and revision of national forest programmes, $\mathrm{FAO}$, Rome

Food and Agriculture Organization of the United Nations. (2009). Asia-Pacific Forestry Sector outlook Study II: Nepal Forestry Outlook Study. Working Paper Series, Working Paper No. APFSOS II/WP/2010/34. Food and Agriculture Organization of the United Nations, Bangkok, Thailand Retrived November 22, 2013 from http://www.fao.org/docrep/014/am250e/am250e00.pdf.

Gibson, C. C., McKean, M. A., \& Ostrom, E. (Eds.). (2000). People and forests: Communities, institutions, and governance. MIT Press. http://dx.doi.org/10.1023/b:huec.0000043619.43907.87

Gilmour D. A., \& Fisher R. J., (1991). Villager, Forest and Forester: The Philosophy, Process and Practice of Community Forestry in Nepal. Kathmandu: Sahayogi Press.

Gupta, S. P., Bhattarai, H. K., \& Sah, R. (2011). Exclusion in Community Forestry of Nepal. A term paper on exclusion in community forestry of Nepal, Kathmandu University, Nepal

Kanel, K. R., \& Dahal, G. R. (2008). Community forestry policy and its economic implications: an experience from Nepal. International Journal of Social Forestry, 1(1), 50-60.

Karky, B. S., Vaidya, R., Karki, S., \& Tulachan, B. (2013). What is REDD+ Additionality in Community Managed Forest for Nepal?. Journal of Forest and Livelihood, 11(2), 37-45. http://dx.doi.org/10.3126/jfl.v11i2.8620

Larson, A. M., Barry, D., Dahal, G. R., \& Colfer, C. J. P. (Eds) (2010). Forests for People: Community Rights and Forest Tenure Reform. London: Earthscan

Lewark, S., George, L., \& Karmann, M. (2011). Study of gender equality in community based forest certification programmes in Nepal. International Forestry Review, 13(2), 195-204. http://dx.doi.org/10.1505/146554811 797406633 
Lund, J. F., Baral, K., Bhandari, N. S., Chhetri, B. B. K., Larsen, H. O., Nielsen, Ø. J., ... Treue, T. (2013). Who benefits from taxation of forest products in Nepal's community forests?. Forest Policy and Economics, 38, 119-125. http://dx.doi.org/10.1016/j.forpol.2013.04.010

Maharjan, M. R., Dhakal, T. R., Thapa, S. K., Schreckenberg, K., \& Luttrell, C. (2009). Improving the benefits to the poor from community forestry in the Churia region of Nepal. International Forestry Review, 11(2), 254-267. http://dx.doi.org/10.1505/ifor.11.2.254

Malla, Y., Schreckenberg, K., \& Springate-Baginski, O. (2002). From supervising" subjects" to supporting" citizens": recent developments in community forestry in Asia and Africa. Overseas Development Institute.

McDougall, C., Jiggins, J., Pandit, B. H., Thapa Magar Rana, S. K., \& Leeuwis, C. (2013). Does Adaptive Collaborative Forest Governance Affect Poverty? Participatory Action Research in Nepal's Community Forests. Society \& Natural Resources, 26(11), 1235-1251.. http://dx.doi.org/10.1080/08941920.2013.779344

Meshack, C. K., Adhikari, B., Doggart, N., \& Lovett, J. C. (2006) Transaction costs of community-based forest management: empirical evidence from Tanzania. African Journal of Ecology, 44, 468-477. http://dx.doi.org/10.1111/j.1365-2028.2006.00659.x

Miller, B. A. (2011). The Gender and Social Dimensions to Livestock Keeping in South Asia: Implications for Animal Health Interventions. Retrived November 22, 2013 from http://r4d.dfid.gov.uk/pdf/outputs/galv/ galvmed-south-asian-gender-report.pdf

Mohammed, A. J. (2014). Decentralization, Forest and Poverty: Framework and Case Studies from Ethiopia. Nova Science Pub Inc, New York.

Mohammed, A. J., \& Inoue, M. (2012a). Drawbacks of decentralized natural resource management: Experience from Chilimo Participatory Forest Management project, Ethiopia. Journal of Forest Research, 17(1), 30-36. http://dx.doi.org/10.1007/s10310-011-0270-9

Mohammed, A. J., \& Inoue, M. (2012b). Explaining disparity in outcome from community-based natural resource management (CBNRM): a case study in Chilimo Forest, Ethiopia. Journal of Environment Planning and Management, 55, 1248-1267. http://dx.doi.org/10.1080/09640568.2011.640171

Nagendra, H., Pareeth, S., Sharma, B., Schweik, C. M., \& Adhikari, K. R. (2008). Forest fragmentation and regrowth in an institutional mosaic of community, government and private ownership in Nepal. Landscape Ecology, 23(1), 41-54. http://dx.doi.org/10.1007/s10980-007-9162-y

Nightingale, A. J., \& Ojha, H. R. (2013). Rethinking Power and Authority: Symbolic Violence and Subjectivity in Nepal's Terai Forests. Development and Change, 44(1), 29-51. http://dx.doi.org/10.1111/dech.12004

Niraula, R. R., Gilani, H., Pokharel, B. K., \& Qamer, F. M. (2013). Measuring impacts of community forestry program through repeat photography and satellite remote sensing in the Dolakha district of Nepal. Journal of environmental management, 126, 20-29. http://dx.doi.org/10.1016/j.jenvman.2013.04.006

Oakerson, R. J. (1992). Analyzing the commons: A framework. Making the commons work: Theory, practice and policy, 41-59.

Ojha, H. R. (2008). Reframing Governance: Understanding Deliberative Politics in Nepal's Terai Forestry . New Delhi : Adroit Publishers.

Ojha, H. R., Persha, L., \& Chhatre, A. (2010). Community forestry in Nepal: A policy innovation for local livelihoods. Proven Successes in Agricultural Development, 123

Ostrom, E. (1990). Governing the Commons: The Evolution of Institutions for Collective Action. New York: Cambridge University Press. http://dx.doi.org/10.1017/cbo9780511807763

Ostrom, E. (2007). Sustainable Social-Ecological System: impossibility? Conference paper presented in meetings of the American Association for the Advancement of Science, 'Science and Technology for Sustainable Well-Being, San Francisco., USA.

Pandit, R., \& Bevilacqua, E. (2011). Forest users and environmental impacts of community forestry in the hills of Nepal. Forest Policy and Economics, 13(5), 345-352. http://dx.doi.org/10.1016/j.forpol.2011.03.009

Paudel, A., \& Weiss, G. (2013). Fiscal policy and its implication for community forestry in Nepal. International Forestry Review, 15(3), 348-354. http://dx.doi.org/10.1505/146554813807700074

Pokharel, R. K. (2009). Pro-poor programs financed through Nepal's community forestry funds: does income matter?. Mountain Research and Development, 29(1), 67-74. http://dx.doi.org/10.1659/mrd.996 
Pulhin, J. M., \& Inoue, M. (2008). Dynamics of devolution process in the management of the Philippines forests. International Journal of Social Forestry, 1(1). 1-26.

Redding, L., Chetri, D. K., Lamichhane, D. K., Chay, Y., Aldinger, L., \& Ferguson, J. (2012). Animal production systems of small farms in the Kaski district of Nepal. Tropical animal health and production, 44(7), 1605-1613. http://dx.doi.org/10.1007/s11250-012-0114-4

Sapkota, I. P., \& Odén, P. C. (2008). Household characteristics and dependency on community forests in Terai of Nepal. International journal of social forestry, 1(2), 123-144.

Satyal Pravat, P., \& Humphreys, D. (2012). Using a multilevel approach to analyse the case of forest conflicts in the Terai, Nepal. Forest Policy and Economics. http://dx.doi.org/10.1016/j.forpol.2012.09.013

Shrestha, K. B., Måren, I. E., Arneberg, E., Sah, J. P., \& Vetaas, O. R. (2013). Effect of anthropogenic disturbance on plant species diversity in oak forests in Nepal, Central Himalaya. International Journal of Biodiversity Science, Ecosystem Services \& Management, 9(1), 21-29. http://dx.doi.org/10.1080/21513732.2012.749303

Smoke, P. (2003). Decentralization in Africa: goals, dimensions, myths and challenges. Public Administration and Development, 23, 7-16. http://dx.doi.org/10.1002/pad.255

Sunam, R. K., \& McCarthy, J. F. (2010). Advancing equity in community forestry: Recognition of the poor matters. International forestry review, 12(4), 370-382. http://dx.doi.org/10.1505/ifor.12.4.370

Sunam, R. K., Banjade, M. R., \& Paudel, N. S. (2010). Can bureaucratic control improve community forestry governance? An analysis of proposed Forest Act amendment. Discussion Paper Series 10: 2, Forest Action.

Sunam, R. K., Paudel, N. S., \& Paudel, G. (2013). Community Forestry and the Threat of Recentralization in Nepal: Contesting the Bureaucratic Hegemony in Policy Process. Society \& Natural Resources, 26(12), 1407-1421. http://dx.doi.org/10.1080/08941920.2013.799725

Uprety, D. R., Gurung, A., Bista, R., Karki, R., and Bhandari, K. (2012). Community Forestry in Nepal: A Scenario of Exclusiveness and its Implications. Frontiers in Science, 2(3), 41-46. http://dx.doi.org/10.5923/ j.fs. 20120203.05

Uprety, Y., Boon, E. K., Poudel, R. C., Shrestha, K. K., Rajbhandary, S., Ahenkan, A., \& Tiwari, N. N. (2010). Non-timber forest products in Bardiya district of Nepal: Indigenous use, trade and conservation. Journal of Human Ecology, 30(3), 143-158.

Webb, E. L., \& Shivakoti, G. P. (Eds.). (2008). Decentralization, Forests And Rural Communities: Policy Outcomes In South And Southeast Asia. India: SAGE

\section{Notes}

Note 1. Bari is an area around the village house where vegetables, fruits and flowers are grown.

Note 2. Passive participation means that although members are physically present in decision-making processes, such as meetings, they either fail to voice their opinion or their voices are not always reflected due to social norms or literacy levels.

\section{Copyrights}

Copyright for this article is retained by the author(s), with first publication rights granted to the journal.

This is an open-access article distributed under the terms and conditions of the Creative Commons Attribution license (http://creativecommons.org/licenses/by/3.0/). 